Esta publicación cientifica en formato digital es continuidad de la revista impresa ISSN-Versión Impresa 0798-1406 / ISSN-Versión on line 2542-3185Depósito legal pp
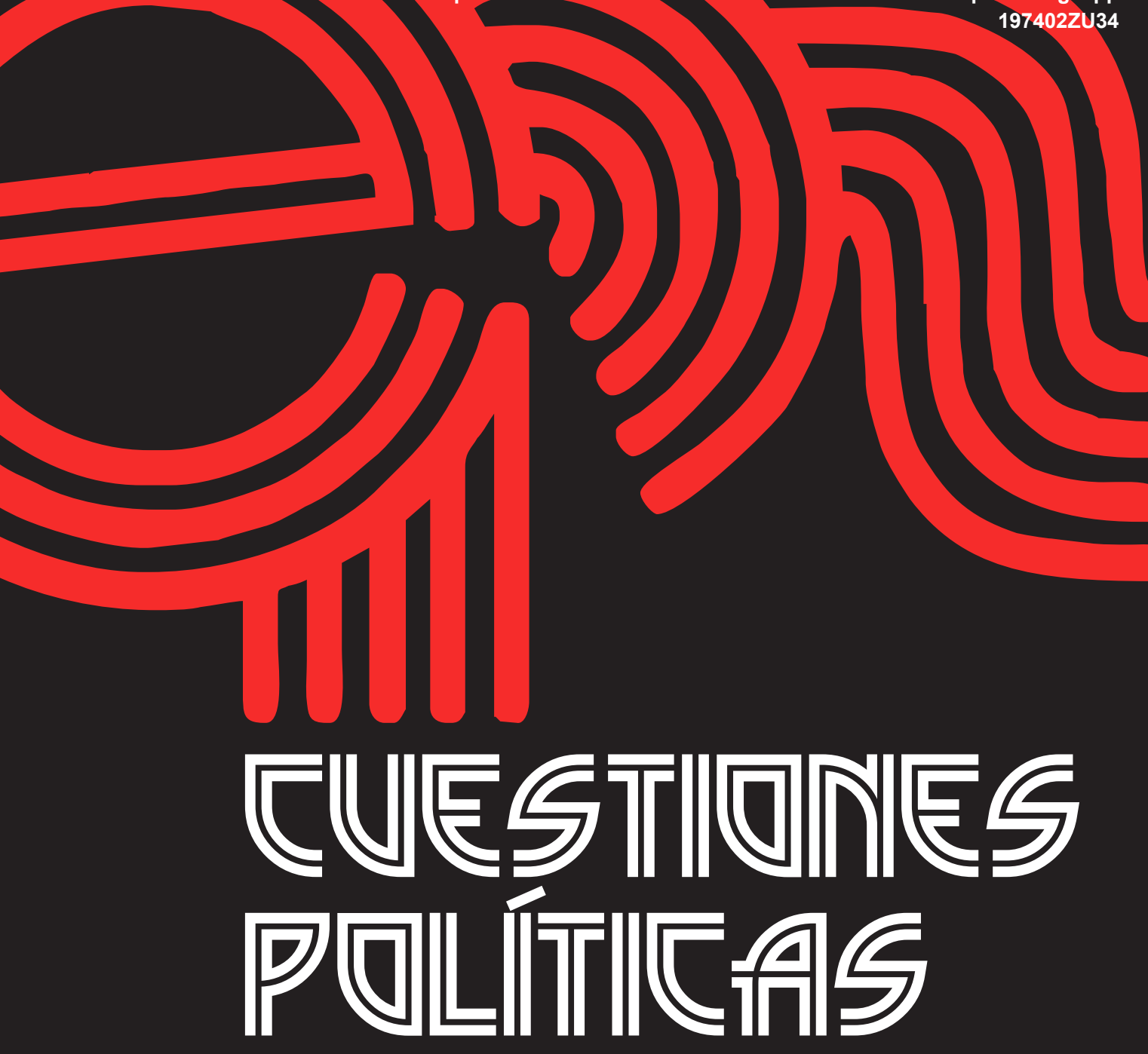

Instituto de Estudios Políticos y Derecho Público "Dr. Humberto J. La Roche" de la Facultad de Ciencias Jurídicas y Políticas de la Universidad del Zulia Maracaibo, Venezuela
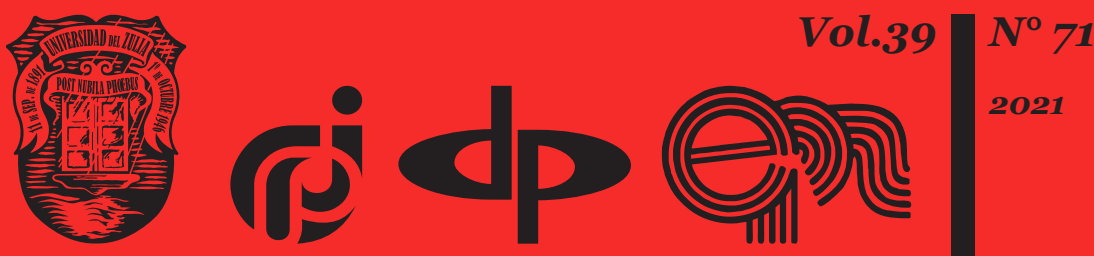


\title{
Culture of legal techniques: key dominants in the modern Russian legal system
}

\author{
DOI: https://doi.org/10.46398/cuestpol.3971.33
}

\author{
Marina V. Baranova * \\ Olga B. Kuptsova ** \\ Sergey N. Belyasov *** \\ Arturas S. Valentonis ****
}

\begin{abstract}
The article is dedicated to the conceptual and specific analysis of the emergence of the culture of legal techniques under the conditions of a new technological form. The identification and analysis of key types of culture of legal techniques, allows to show their specificity following typological groups. Its systemic unity, which has its specificities, can be considered as the second dominant of the culture of legal techniques. The article further offers a primary doctrinal definition of the concept of culture of legal techniques based on the identified dominant characteristics and manifestations of the culture of legal techniques, studied in the context of the search for ways of effective functioning of the system of power and powerless principles in the Russian legal system. This phenomenon is in the formation stage. The authors have used dialectical, historicalpolitical, formal-legal, and comparative-legal methods. It is concluded that a promising systematic understanding of the essence and meaning of the culture of legal techniques will help to improve the legal culture as a whole and thus increase the effectiveness of the law in modern society.
\end{abstract}

Keywords: legal culture; deliberation; digitization; power and impotence in law; dominant aspects.

* National Research Nizhny Novgorod State University named after N.I. Lobachevsky, Nizhny Novgorod, Russia. ORCID ID: https://orcid.org/oooo-0oo1-6392-9843

** National Research Nizhny Novgorod State University named after N.I. Lobachevsky, Nizhny Novgorod, Russia. ORCID ID: https://orcid.org/oooo-0003-0124-7745

*** State University of Humanities and Technology (GGTU), Orekhovo-Zuyevo, Russia. ORCID ID: https://orcid.org/oooo-0003-2059-2413

**** State University of Humanities and Technology (GGTU), Orekhovo-Zuyevo, Russia. ORCID ID: https://orcid.org/oooo-0002-8212-7157

Recibido el 02/09/2021

Aceptado el 22/11/2021 


\section{Cultura de las técnicas jurídicas: dominantes clave en el sistema jurídico ruso moderno}

\section{Resumen}

El artículo está dedicado al análisis conceptual y específico del surgimiento de la cultura de las técnicas jurídicas en las condiciones de una nueva forma tecnológica. La identificación y análisis de tipos clave de cultura de las técnicas jurídicas, permite mostrar su especificidad siguiendo grupos tipológicos. Su unidad sistémica, que tiene sus especificidades, puede considerarse como la segunda dominante de la cultura de las técnicas jurídicas. El artículo además ofrece una definición doctrinal primaria del concepto de cultura de las técnicas jurídicas basada en las características y manifestaciones dominantes identificadas de la cultura de las técnicas jurídicas, estudiada en el contexto de la búsqueda de formas de funcionamiento efectivo del sistema de poder y los principios impotentes en el sistema jurídico ruso. Este fenómeno se encuentra en la etapa de formación. Los autores han utilizado métodos dialécticos, históricopolíticos, formales-legales y comparativos-legales. Se concluye que una comprensión sistemática prometedora de la esencia y el significado de la cultura de las técnicas jurídicas ayudará a mejorar la cultura jurídica en su conjunto y, por lo tanto, a aumentar la eficacia del derecho en la sociedad moderna.

Palabras clave: cultura jurídica; deliberación; digitalización; poder e impotencia en derecho; aspectos dominantes.

\section{Introduction}

The modern reality, conditioned by a new technological way of being, requires a new look at the interaction of man and the "state machine", a different specificity, and the development of clear permissible boundaries. Therewith, the awareness of legal information, the perception of legal innovations, the arrangement of a communicative action focused on achieving mutual understanding and consent (Habermas, 2000) does not lose relevance, especially within the framework of legal practice.

The need for equal, open dialogue between the state and society is of particular importance in the current realities, which is possible only in the conditions of adequate, thoughtful use of technical and legal tools by a wide range of persons with different levels and volumes of legal knowledge, skills, and abilities. The promising development of law today is presented in the conditions of a partnership dialogue between the power (state) and powerless (social) principles that have common legal and cultural grounds. 
As A.S. Bondarev (2010) rightly notes, legal culture is a concrete historical phenomenon since the degree of legal maturity is directly dependent on the concrete historical stage of development of society and its legal values. Foreign researchers also point to the enduring claims of culture as a necessary and inevitable mechanism by which people construct meaning from existing reality (Rose, 2006, p. 102). It is also noted that the legal culture is a direction of research on relatively stable patterns, focused primarily on the specifics of social relations and behavioral reactions (Nelken, 1997, p. 69).

In general, the relevance of this problem, the need for its research, and the predetermination of the transformation of the legal system depending on the characteristics of the legal culture of a certain period have been emphasized in foreign legal doctrine for decades (Cowan, 2004; Friedman, 1975; Gibson, Caldeira, 1996; Wilhelmsson et al., 2007). The ideas of a partnership between the state and society in the modern Russian legal system, typical of the European model of statehood, have undergone significant changes, following the specifics of the national and legal culture, which is natural and justified.

Building an effective mechanism for such interaction using the achievements of technological progress is inevitable and desirable, but, at the same time, it is very difficult, is ambiguously evaluated by society, and can lead to bipolar consequences. It should be recognized that any innovation requires time, implementation efforts, and adjustments. The construction of legal communication in a new format, by unusual means, is aimed at a more extensive introduction of the ideas of deliberative democracy, embodying in real life the equal interaction of the power and powerless principles of law through special technical and legal tools.

Already today, an active policy of integrating information technologies that mediate legal communication into the activities of state authorities is being implemented. There are calls to: "Digitalize the entire system of public administration, increase the transparency of the activities of state structures, increase the speed of processing citizens' appeals, reduce bureaucratic barriers, introduce new forms of interactive communication with citizens" (Bakanova, 2020: 24). The same trends take place in the modern foreign legal doctrine. Scholars are increasingly turning to a comprehensive study of cultural phenomena from the positions of both legal and social analysis, they need a deeper understanding and appeal to irrational approaches or more variable aspects of the rationality of public life (Cotterrell, 2006). 


\section{Methods}

Author have used dialectical, historical-political, formal-legal, comparative-legal methods.

\section{Results}

Modern national legal systems function within the process of technologization and permanent dialogue of cultures, which actualizes the understanding of the elements of the language of the law that serve the purpose of the effective functioning of the power and powerless principles of law. The harmonious, interdependent coexistence of power and powerless beginnings enriches the legal culture and legal practice, providing innovative opportunities for the use of technical and legal tools, creates a resource for effective legal communication between the state and society.

Many researchers emphasize that the legal culture is a poly structural formation (Kartashov and Baumova, 2008). Moreover, some of its components have not been studied, and the attempt to comprehend such an important phenomenon as a culture of legal techniques is an important stage in the development of legal doctrine. Technical and legal culture is a differentiated part of the legal culture, which is characterized by a system of technical and legal (power) and ethical and deontological (powerless) values.

This phenomenon reveals and states the level of development of legal technology in the state, the degree of awareness of the need for a respectful attitude to technical and legal tools. The technical and legal culture serves as the basis for the effectiveness of the implementation in the legal practice of professional legal rules, techniques, means necessary for the qualitative functioning of the spheres of law-making, legal interpretation, power and powerless implementation of the law, ensuring the perfection of the form and content of the law.

The technical and legal culture within the framework of legal practice is based on the perception of the subject from the standpoint of his/her culture, his/her knowledge, and ability to own technical and legal tools. Technical and legal culture as an independent phenomenon is currently in the stage of formation, its active development will contribute not only to the improvement of legal culture in general but also to the development of various spheres of modern society.

The problem of determining the main dominants of various manifestations of the existence of culture as a systemic and integral 
phenomenon is not new. Several studies are devoted to this, emphasizing the most important system-forming foundations of cultural phenomena, which allow understanding the process of their formation and genesis. For example, cultural dominants are understood as the most essential meanings for a certain culture, the totality of which forms a type of culture (Frolova, 2017). Of the existing variations of a cultural nature that reveal this category, understanding it in line with the dominant idea that reveals the essence and content of the analyzed legal phenomenon will play a scientific and practical significance as the main semantic meaning.

\section{Discussion}

It is necessary to recognize the increasing relevance of legal knowledge in the conditions of active legalization of relations, which determines the immersion in legal regulatory processes not only of subjects of legal practice but also of citizens. The legal culture of society comes to the fore, since:

...the legal mechanism is a complex apparatus, for the effective operation of which a purposeful spiritual activity of all members of society is required. Each individual, by his/her participation in the exercise of the right, transforms the necessary into the requirement of the due in social relations. This creative process is possible only due to the conscious and volitional activity of all members of society - self-sufficient citizens of their state (Karasik, 2002: 128).

The legal culture of modern Russian society is characterized by a change in its essential basis, which is based on the revival of a series of traditions, the formation of innovations in line with the active processes of digitalization of society. Currently, there is a solid accumulated experience of doctrinal and scientific-practical developments containing a system of requirements for the creation of various types of legal acts developed in line with the Nizhny Novgorod scientific school under the leadership of V.M. Baranov.

In this regard, the basis of this accumulated heritage, its popularization, and practical implementation gives reason to believe that there is a need to distinguish and delimit an independent legal category from related legal phenomena - culture of legal techniques. The prerequisites for its isolation have gradually developed over a certain amount of time, and recently several researchers have revealed its aspects to one degree or another. For example, V.M. Baranov refers to lawmaking culture (2018, p. 1), G.A. Tosunyan and L.V. Sannikova investigate the culture of lawmaking (2018, p. 28-34), L.A. Petruchak highlights the culture of lawmaking and law enforcement (2012, p. 304), S.N. Boldyrev highlights the culture of legal technology (2011, p. 37), and S.A. Bogolyubov characterizes the culture of the legislative technique (2006, p. 52). This list can be continued. 
The prospective relevance of the study of the culture of legal techniques is based, first of all, on the challenges of legal practice, which determine a set of clear requirements for the professional activity and training of a lawyer. The realities of life dictate the need to form not only a wide range of special knowledge, mastery of techniques and means of legal technology, but also real skills and abilities of their implementation in the proposed conditions. Only in this case can we talk about the effectiveness of the lawyer's activity, the effectiveness of the functioning of the law as a whole.

Today, the legal technique harmoniously combines the power and powerless principles. Being aware of the familiarity and primacy of the power component, which is subjected to regular doctrinal analysis, it is necessary to recognize the need to address powerless aspects that cause a different manifestation outside of the technical and legal tools. Initially, the basic component of ideas about legal technology was the imperious principle of lawmaking technology in Russian legal science (narrow approach).

Later, an approach took root that combined the spectrum of power and powerless legal activities and the typical special tools for this (a broad approach). In the context of this approach, the subject series allows talking about the technique of power and powerless legal activity. Indeed, not all subjects of legal communication have authoritative powers, which means that it is quite justified to single out and analyze these types of legal equipment, but everything is ambiguous in the real relations of the state and society - the types are sometimes difficult to separate, especially in the conditions of technologization.

Theuse of the Internethas simplified and acceleratedlegal communication and legal acculturation. The globalized, legalized reality for the participation of the dialog requires the special legal knowledge, authoritative powers, possession of the skill of using special technical and legal forms. Within the framework of legal practice, it is assumed that there is a power, or an action on behalf of the power, on the authority's instructions, within the framework of power requirements, forms, competence, mandates.

It should be particularly noted that the professional activity of a lawyer includes a powerless component - the requirements for functional professional suitability, the required socio-psychological qualities. The component that characterizes the personality allows not only identifying accentuations, character traits, possible dominant behaviors, willingness to cooperate but also affects the set and combination of power and powerless culture of legal techniques tools required in the future. Ultimately, it affects the level of legal technology in general. The legal doctrine has now been confirmed in the opinion about the importance of the role of legal technology for identifying the level and quality of the legal culture of society. 
572 Marina V. Baranova, Olga B. Kuptsova, Sergey N. Belyasov y Arturas S. Valentonis

Culture of legal techniques: key dominants in the modern Russian legal system

Jurisprudence continues to develop intensively and opens up new meanings of established phenomena, which actualizes the rethinking of the conceptual apparatus. Thus, approaches to the definition of the concept of culture as a whole today differ in variability and discussion. Therewith, the axiological approach is dominant, focusing on the significant, positive results of people's activities, on the good produced. As G.P. Vyzhletsov rightly noted, who justified the concept of the axiology of culture, the value doctrine of culture, unlike many other theoretical approaches to it, allows seeing culture from the inside (Vyzhletsov, 1996, p. 3). From the point of view of this concept, legal culture in a general abstract understanding is a set of legal values developed by humanity, reflecting the progressive legal development of society.

The essential basis of legal culture is manifested in the process of influencing the formation and modernization of significant social institutions. Having a systematic character, the legal culture absorbs and arranges legal values, fixes the level of development of legal technology, the instrumental value of law within a specific period. The legal culture in Russia has a pronounced feature - it has been historically developed based on the basic value guideline of "truth"/justice"/"conscience", and the echoes of the key components of this approach, to one extent or another, manifest themselves in the modern legal culture of the country, and the national legal system as a whole. Initially, these components served to evaluate behavior, choose a model of behavior, and the form of exercising the functions of law.

Understanding of the law, the requirements of state-power dictates and the idea of "truth"/"justice"/"consciences" have been conflicting for a long time, causing conflict situations. The law has always remained the universal guarantor of order in society. The concept of "truth"/"justice"/"conscience", as a basic measure in legal (power) and other social (powerless) issues, still exists organically in the national legal system. It is resistant to destabilization, can modernize following the realities. The specificity of the understanding of legal culture is manifested in modern legal institutions, determines the interaction of the state and society, the ratio of power and powerless principles in legal technology, the elevation of a particular phenomenon, object to the rank of value.

The range of values underlying the system of assessment of legal phenomena and processes also extends its influence on non-legal regulators (powerless), since they are more or less conditioned by law (power), are interconnected with it, are mediated by it, and mediate it. Currently, social non-legal regulators attract the attention of legal scholars, since their importance for a wide range of relations is visible. For example, Professor Yu.A. Tikhomirov, referring to the issue of the admissibility of a prospective merger of legal and non-legal regulators, proposed his vision of the social 
concept of law. He noted in a study on forecasts and risks in law, that: "Social regulators in Russian legislation are reflected in the content of economic and other branches of law" (Tikhomirov, 2015: 97).

An emphasis on legal and non-legal social norms, an understanding of their value directly, an analysis of related legal values will allow for more effective implementation of legal regulation. R.Pento and M. Gravitts, analyzing the methods of social sciences, noted that: "various social norms can act as legal norms" (Pento and Gravitts, 1972: 54).

Recognizing the validity of the conclusion about the inseparable connection of legal and non-legal, power, and powerless regulators and instruments of influence, it should be assumed that this has a significant impact on the specifics of legal technology, legal culture, culture of legal techniques concerning various types of legal practice.

In this regard, the analysis of the possibility of a specific division of technical and legal culture following the distinguished varieties of legal technology - lawmaking, interpretive law, law enforcement, law systematizing, and others, acquires special relevance. Turning to the analysis of the characteristic features of the formation of the legal phenomenon under study, we note the most important of them following the specified typological groups.

The specifics of the law-making legal technique have received quite detailed coverage in doctrinal research. Currently, there is a need for professional specialists who would have the skills to prepare high-quality regulatory legal acts and other sources of law, based on a mature culture of legal techniques consciousness, awareness of the need to prepare highquality regulatory documents. We should not discount the activation of citizens' involvement in the processes of deliberation.

The Russian state expresses its power interest in this, for example, a serious step was taken in 2011 in recognizing the value of the participation of a wide range of citizens in the process of legal education - the following entered into force: Decree of the President of the Russian Federation No. 167 of February 9, 2011:

On the public discussion of the draft Federal Constitutional laws and federal laws" and Decree of the President of the Russian Federation No. 183 of March 04, 2013 "On consideration of public initiatives sent by citizens of the Russian Federation using the Internet resource "Russian Public Initiative.

The complexity of this task should be noted while recognizing the unconditional importance of deliberative processes. The insufficiency, and, sometimes, the complete lack of legal knowledge, skills in dealing with a legal matter, technical and legal tools programmable causes difficult-toovercome or unavoidable problems in underestimating the current and 
desired legal regulations. The available range of technical and legal means is unreasonably narrowed, approaches, forms are primitivized, ideas are impoverished.

Professional knowledge of legal technology provides a wealth of opportunities and tools, the appropriate choice of which is based on systemic legal knowledge, specific critical thinking, experience, skills, and abilities. This is especially important in law-making; therefore, we should agree with the position of Professor V.M. Baranov on the need to professionalize the rule-making process. At this stage of development and demand for practical knowledge about legal technology, the issue of organizing the training of "norm-writers" - specialists who do not pass regulatory legal acts, namely, write them, develop the structure and architectonics of the document (Baranov, 2017) is relevant.

The gradual formation of a positive attitude to the use of foreign language vocabulary in the textual expression of normative prescriptions of various sources of law should also be noted among the characteristic features of the culture of legal techniques. This is a reflection not only of the developing legal culture of society, which is characterized by the revival of the traditions of Latin legal terminology in the language of law and the language of legal doctrine but is also a consequence of the development of linguistic culture, which, in the context of digitalization of public relations, is distinguished by the active introduction of foreign lexis into the vocabulary. Reasonably and timely used foreign lexis contributes to the development of law, its enrichment with new constructions that have a more effective regulatory potential.

In addition, one more dominant feature of the modern culture of legal techniques should be noted - the development of the variability of technical and legal consciousness. Currently, there are active processes of transformation of the existing ideas about the formulation and specifics of regulatory requirements and their relationship with other phenomena. The specifics of the analysis and processing of legal information are changing in our era of the second modernity. In this regard, it is necessary to work out options for operating with legal norms that are combined into certain complexes of a systemic nature and to use a different structuring of normative material in their work.

There is no doubt that at present this is not yet a requirement of legal reality, but it is necessary to understand and form the prerequisites for the development of this area of activity right now so that the legal system and specialists are ready for changes in social reality in general and legal reality. There are reasons to believe that in line with these legal transformations, research on topics in law will be constructive, timely, and in demand by legal practice. The tops of the legal language as structural and semantic models of a linguistic nature have a significant potential for improving the legal and technical components of the legal matter. 
The normative institutions of the modern system of sources of law are gradually changing both of a substantive and formal nature in connection with the ongoing processes of globalization and digitalization of law. In this line of transformation processes, topical jurisprudence can be positioned as one of the most important areas of the foundations not only of the culture of the legal language but also of the technical and legal culture. The top of the legal language should include the structural elements of the text of a legal act, which have their content and interact with each other, determining the additional internal structuring of law, as well as interpretative and law enforcement provisions.

It is important to note that the understanding of the text, the conceptual apparatus is significantly influenced by the specifics of the personality of the subject of perception. Differences in the educational level, the specifics of knowledge, social status, life experience, the degree of language proficiency, mental characteristics play a significant role. There is a wellestablished belief in jurisprudence that the legal language forms specific legal thinking. The versatility and consistency of the key components of the legal language allow clearly and correctly expressing, understanding, explaining, implementing (power and powerless) the normative command.

\section{Conclusion}

The globalized world involves national legal systems in active legal acculturation, interaction in social and political spheres, which actualizes the appeal to the study of modern processes of transterminologization, universalization, standardization of elements of the language of the law that serve the purpose of effective functioning of the system of power and powerless principles of modern Russian law.

This system can be considered as one of the most important dominants of the modern culture of legal techniques, which has a system-forming character and allows identifying the main trends not only of its formation but also of development in line with the progressive development of postindustrial society.

The interdependence of these principles in the national law of Russia, in the legal technique, as previously noted, is historically due to the balance of state power dictates and the value guideline of "truth"/"justice" formed in the legal culture/"conscience". The harmonious, mutually conditioned coexistence of power and powerless principles enriches the legal culture and legal practice, providing innovative opportunities for using technical and legal tools, creating a resource for effective legal communication between the state and society. 
576 Marina V. Baranova, Olga B. Kuptsova, Sergey N. Belyasov y Arturas S. Valentonis

The culture of legal techniques within the framework of legal practice is based on the perception of the subject from the standpoint of his/her culture, his/her knowledge, and ability to own technical and legal tools.

Based on the dominant features and manifestations of culture of legal techniques, we can offer a primary definition of the concept of culture of legal techniques:

Culture of legal techniques is a part of legal culture, which is a system of technical and legal (power) and ethical-deontological (powerless) values, the level of development of legal technology, conscious respect for technical and legal tools, which serves as the basis for the effectiveness of the implementation in the legal practice of professional legal rules, techniques, means necessary for the qualitative functioning of the spheres of lawmaking, legal interpretation, power and powerless implementation of the law, ensuring the perfection of the form and content of the law.

The significance of the culture of legal techniques and its level for the legal system can be formulated based on the well-established approach in Russian jurisprudence to the essence and value of legal culture as a whole. If: "... the level of culture reflects the measure of reproducibility of order factors as opposed to the chaotic state of public life" (Maltsev, 2013: 6), then the conclusion about the indisputable value of culture of legal techniques as a promising phenomenon reflecting the measure of proper order in legal technology, as opposed to the existing state, problems, deviations from strict and justified technical and legal requirements in all spheres of legal practice, both power and powerless, seems quite justified.

Promising culture of legal techniques as an independent phenomenon will continue its formation. It can be argued with a high degree of confidence that its active development will contribute to the further improvement of legal culture, the transformation of key areas of society, the entirely legal system.

\section{Bibliographic References ${ }^{5}$}

BAKANOVA, E.A. 2020. Technoscience in the Information Society: SocioPhilosophical Analysis: abstract of a thesis of Candidate of philosophical sciences. Tomsk, Russia.

BARANOV, Vladimir Mikhailovich. 2016. "Culture and legal technique: Introductory remarks” In: Yuridicheskaya tekhnika. No. 10, pp. 10-22.

5 Some cited sources only have the initial of the name of the author or authors because it was impossible to locate their full name as stable the standard of this journal. 
BARANOV, Vladimir Mikhailovich. 2017. "Norm-writer as a profession" In: Vestnik Saratovskoi gosudarstvennoi yuridicheskoi akademii. No. 6, pp. 16-29.

BOGOLYUBOV, S.A. 2006. "Culture of legislative technique" In: Zhurnal rossiiskogo prava, No. 10, pp. 52-55.

BOLDYREV, S.N. 2011. "Legal culture of society and culture of legal technology" In: Filosofiya prava [Philosophy of law]. Vol. 15, No. 22. pp. 36-40.

BONDAREV, A.S. 2010. "Legal culture and products of legal culture in their relationship" In: Vestnik Permskogo universiteta. Yuridicheskie nauki. Vol. 2, No. 8, pp. 8-15.

COTTERRELL, R. 2006. Law, Culture and Society. Aldershot. UK, London.

COWAN, D. 2004. “Legal Consciousness: Some Observations" In: Modem Law Review. Vol. 67, No. 6, pp. 122-139.

FRIEDMAN, Lawrence M. 1975. The Legal System: A Social Science Perspective. Russell Sage Foundation. UK, London.

FROLOVA, E.A. 2017. Methodology and philosophy of law: from Descartes to Russian neo-Kantians. Monograph. Moscow, Russia.

GIBSON, James L; CALDEIRA, Gregory A. 1996. The Legal Cultures of Europe, Law \& Society Review. Berkeley Law. California, USA.

HABERMAS, Jurgen. 2000. Moral awareness and communicative action. Norma. Saint Petersburg, Russia.

KARASIK, V.I. 2002. Language circle: personality, concepts, discourse. Peremena. Volgograd, Russia.

KARTASHOV, V.N., BAUMOVA, M.G. 2008. Legal culture: concept, structure, functions. Monograph. Yaroslavl, Russia.

MALTSEV, G.V. 2013. Cultural traditions of law. Monograph. Moscow, Russia.

NELKEN, D. 1997. "Puzzling Out Legal Culture: A Comment on Blankenburg" In: Comparing Legal Cultures. Brookfield. Toronto, Canada.

PENTO, R; GRAVITTS, M. 1972. Social Science Methods. Spectral. Moscow, Russia.

PETRUCHAK, L.A. 2012. Legal culture of modern Russian society: theoretical and legal research. Dissertation of the candidate of legal sciences. Moscow, Russia. 
Marina V. Baranova, Olga B. Kuptsova, Sergey N. Belyasov y Arturas S. Valentonis

578 Culture of legal techniques: key dominants in the modern Russian legal system

ROSEN, L. 2006. Law as Culture. Princeton. New Jersey, USA.

TIKHOMIROV, YU.A. 2015. Law: Forecasts and Risks: Monograph. Institute of Legislation and Comparative Law under the Government of the Russian Federation. Moscow, Russia.

TOSUNYAN, G.A; SANNIKOVA, L.V. 2018. "The culture of lawmaking in modern Russia” In: Gosudarstvo i pravo. No. 3, pp. 28-34.

VYZHLETSOV, G.P. 1996. Axiology of culture. Norma. Saint Petersburg, Russia.

WILHELMSSON, Thomas; PAUNIO, Elina; POHJOLAINEN, Annika. 2007. Private Law and the Many Cultures of Europe. Available online. In: https://lawcat.berkeley.edu/record/214253. Date of consultation: $12 / 12 / 2020$. 

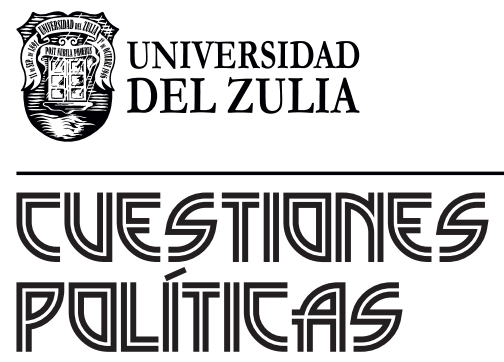

Vol. 39 N $^{\circ} 71$

Esta revista fue editada en formato digital y publicada en diciembre de 2021, por el Fondo Editorial Serbiluz, Universidad del Zulia. Maracaibo-Venezuela 